\title{
Breath biomarkers in toxicology
}

\author{
Joachim D. Pleil ${ }^{1}$
}

Received: 30 June 2016 / Accepted: 4 August 2016 / Published online: 1 September 2016

(C) Springer-Verlag Berlin Heidelberg (outside the USA) 2016

\begin{abstract}
Exhaled breath has joined blood and urine as a valuable resource for sampling and analyzing biomarkers in human media for assessing exposure, uptake metabolism, and elimination of toxic chemicals. This article focuses current use of exhaled gas, aerosols, and vapor in human breath, the methods for collection, and ultimately the use of the resulting data. Some advantages of breath are the noninvasive and self-administered nature of collection, the essentially inexhaustible supply, and that breath sampling does not produce potentially infectious waste such as needles, wipes, bandages, and glassware. In contrast to blood and urine, breath samples can be collected on demand in rapid succession and so allow toxicokinetic observations of uptake and elimination in any time frame. Furthermore, new technologies now allow capturing condensed breath vapor directly, or just the aerosol fraction alone, to gain access to inorganic species, lung $\mathrm{pH}$, proteins and protein fragments, cellular DNA, and whole microorganisms from the pulmonary microbiome. Future applications are discussed, especially the use of isotopically labeled probes, non-targeted (discovery) analysis, cellular level toxicity testing, and ultimately assessing "crowd breath" of groups of people and the relation to dose of airborne and other environmental chemicals at the population level.
\end{abstract}

Disclaimer: The United States Environmental Protection Agency through its Office of Research and Development has subjected this article to Agency administrative review and approved it for publication. Mention of trade names or commercial products does not constitute endorsement for use.

Joachim D. Pleil

pleil.joachim@epa.gov

1 Office of Research and Development, U.S. Environmental Protection Agency, Research Triangle Park, NC 27711, USA
Keywords Human exposome · Exhaled breath · Breath condensate $\cdot$ Cellular respiration $\cdot$ Mass spectrometry . Adverse outcome pathway

\section{Introduction}

Exhaled breath testing is a broad topic that of conjures up images of police officers and forensic alcohol tests, hospitals and anesthesiology, pulmonary function examinations (spirometry) for asthma and emphysema, and oxygen uptake training in sports medicine as illustrated in Fig. 1. The trace-level analytical techniques used for toxicology and the high-tech medical, clinical, and environmental applications are rarely what come to mind first. However, breath has now joined blood and urine as an important diagnostic biofluid for all kinds of analyses for chemical exposures, biological response, metabolism kinetics, health state assessment, multiple time point assessments, and toxicological effects monitoring (Perbellini et al. 2003; Wallace et al. $1987 \mathrm{a}, \mathrm{b}, \mathrm{c})$. In fact, breath biomarkers have demonstrated particular advantages over blood and urine in that breath sampling provides an essentially inexhaustible supply, does not require medical personnel or privacy, is noninvasive, and does not produce potentially infectious waste such as needles, bandages, and glassware (Wallace et al. 1986; Amann and Smith 2005; Pleil 2008).

\section{The human exposome}

The interaction of exogenous chemicals with human life processes or "systems biology" has taken on a new and overarching meaning for long-term latency or chronic diseases like cancer and cardiopulmonary disease, autoimmune and neurodegenerative diseases including 

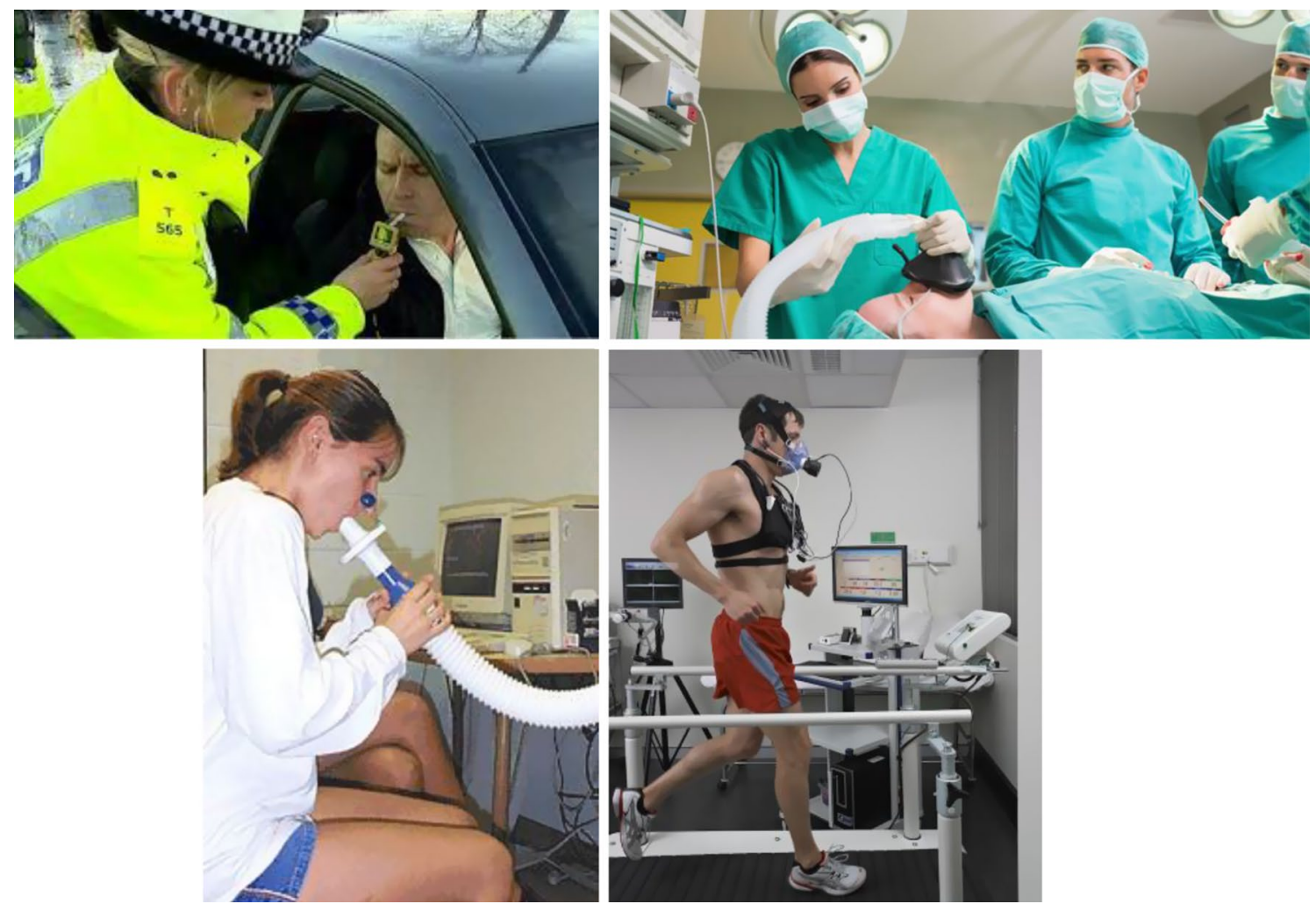

Fig. 1 Commonly held conceptions of applications for breath monitoring: law enforcement, anesthesia, spirometry, and exercise physiology

Parkinson's, Alzheimer's, Lupus, and scleroderma, and a variety of developmental disorders such as autism, spina bifida and cerebral palsy (Pleil 2008, and references therein). The conventional wisdom that disease incidence is "bad luck" is losing traction; it is now recognized that the "gene $\times$ environment" interaction is likely the cause and that chronic exposures to toxic environmental compounds, whether individually or in concert, instigate longterm processes that can ultimately overwhelm repair and defense mechanisms (Smith and Rappaport 2009; Rappaport and Smith 2010). As such, the human exposome has been proposed as the repository of the chemicals and interaction products that need to be cataloged and interpreted to assess disease processes, and in the long run direct intervention measures (Lioy and Rappaport 2011; Wild 2012; Miller and Jones 2014; Sexton et al. 2004). Originally, human exposome research focused on blood-borne chemicals as the blood contacts all living cells and is considered the "central compartment" (Rappaport et al. 2014). Certain constituents of the exposome are now monitored in other biological fluids for easier access, higher concentrations, and closer proximity to specific organs (e.g., urine for kidney and bladder, lung lavage fluid and breath for lung, cell lines for microbiome and tissues) (Vrijheid et al. 2014; Pleil et al. 2014a, b; Pleil and Stiegel 2013; Amann et al. 2014a, b). The use of breath patterns has even been proposed as a form of ultimate fingerprint like the genome by using portable devices (Risby and Pleil 2014; Stix 2003; Fridman et al. 2015). In the following discussions, the focus is on the breath exposome as a tool for toxicity testing and evaluation.

\section{Gas-phase breath sampling and analysis}

Breath biomarkers, pulmonary physiology, and various gas-phase analytics are now emerging as important toxicological research applications (Manolis 1983; Droz and Guillemin 1986; Lippmann and Schlesinger 2000; Miekisch et al. 2004; Cao and Duan 2007). Breath biomarkers have been implemented in a variety of occupational applications as well, for example firefighters' turnout gear has been tested for safety, fuel systems personnel in the military have been monitored for jet fuel exposures, and industrial workers have been tested for nanoparticle exposures (Pleil et al. 2014a, b; Tu et al. 2004; Pelclova et al. 2015). Although not discussed in detail here, the dental research community has also embraced gas-phase analytical technology to assess and mitigate causes of halitosis both as an adverse condition and as a symptom of underlying periodontal disease (Seemann et al. 2014; Laleman et al. 2014). The medical research community is focusing on exhaled breath patterns to indicate preclinical disease state for lung 

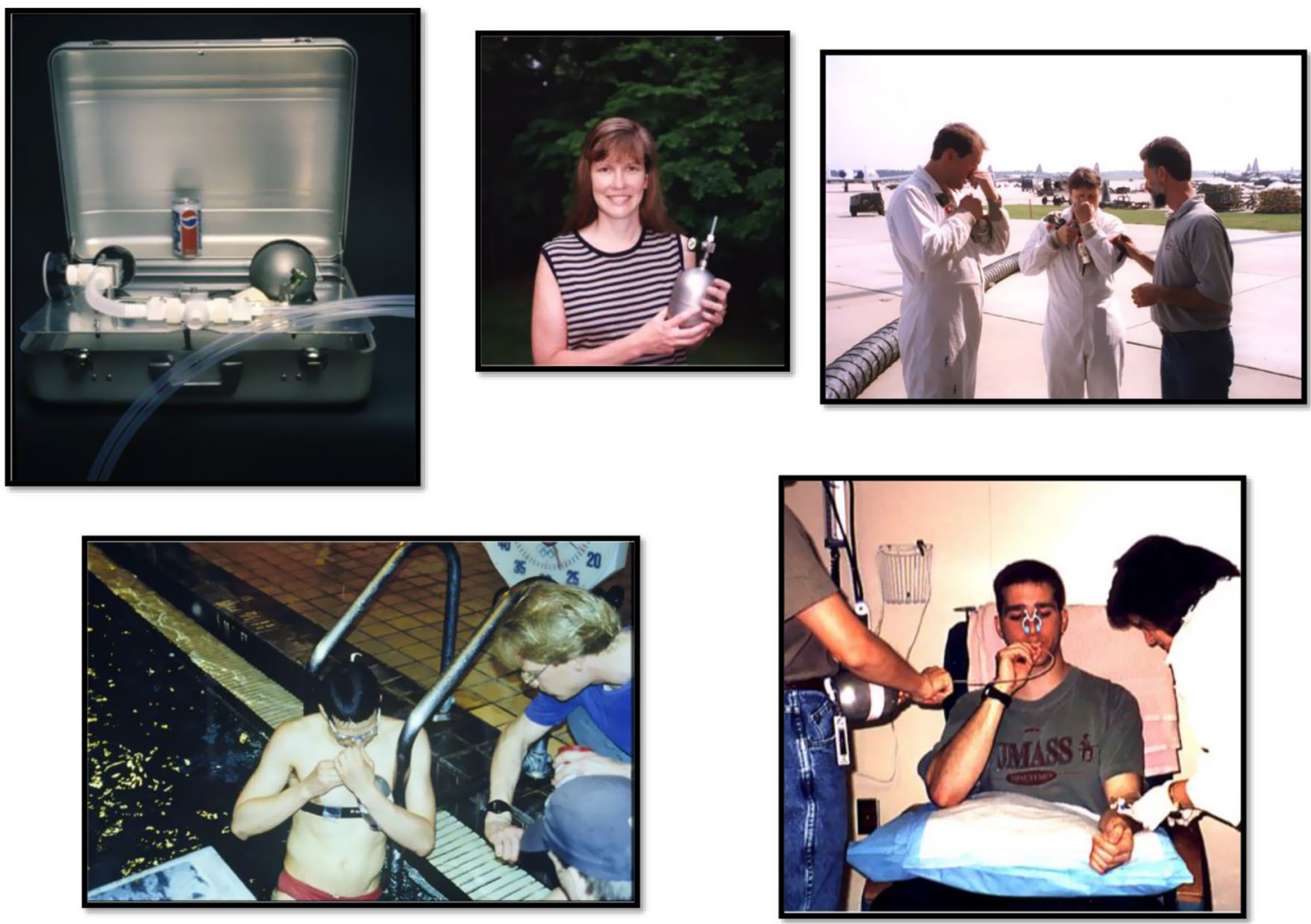

Fig. 2 Canister-based breath sampling: non-rebreathing device for multiple-breath collections (upper left); different examples of single-breath collection device (1-1 evacuated canister), and simultaneous blood and breath sampling in an exposure study (lower right)

cancer, COPD, and other diseases (Filipiak et al. 2014; Lázár et al. 2014; Arasaradnam et al. 2016) and has even embraced canine olfaction as an alternative analytical tool (Jezierski et al. 2015).

The aforementioned techniques are all based on the exhaled breath, which can be measured using spirometry, analyzed with various real-time instruments, collected in canisters (illustrated in Fig. 2) or transferred onto adsorbent tubes for subsequent analysis by gas chromatography-mass spectrometry (GC-MS). Typically, these methods focus on volatile organic compounds (VOCs) related to exposure. Specifically, the gas-phase analyses are useful for:

- Pulmonary function/inflammatory response testing.

- Estimating exposure and dose of VOCs from fuels, consumer products, solvents, disinfection by-products, etc.

- Developing toxicokinetic models for absorption, distribution, metabolism, and excretion (ADME) of VOCs.

- Linking toxicity from in vitro test to in vivo effects.

- Assessing metabolism with isotopically labeled compounds.

Exhaled breath is the best-suited biofluid for direct access to physiological changes in lung function and the "exposure to effect" pathway of the toxicity of exogenous gas-phase chemicals. This is particularly true for any analytical schemes that require rapid response; unlike blood and urine sampling, breath can be sampled essentially in real time (adjacent breaths) and is inexhaustible (Amann et al. 2014a, b; Beauchamp 2011; Pleil et al. 2011; Vaittinen et al. 2013); in fact, these features of "quick and noninvasive" were the original reasons for converting forensic alcohol analysis (for drunk driving) from blood to breath testing (Dubowski 1974).

\section{Vapor, aerosol, and particulate phase breath sampling and analysis}

There is an additional arena of analytical procedures that use exhaled breath condensate (EBC) or the subset of exhaled breath aerosol (EBA) fraction of whole breath (Grob et al. 2008; Mutlu et al. 2001; Johnson and Morawska 2009; Almstrand et al. 2008). EBC is collected by passing breath through a chilled tube and freezing out the water vapor, dissolved (polar) organics, and any associated particulates, bacteria, proteins, etc., in the exhaled aerosols and vapors; although researchers have developed various "home-built" devices, self-administered kits are available 

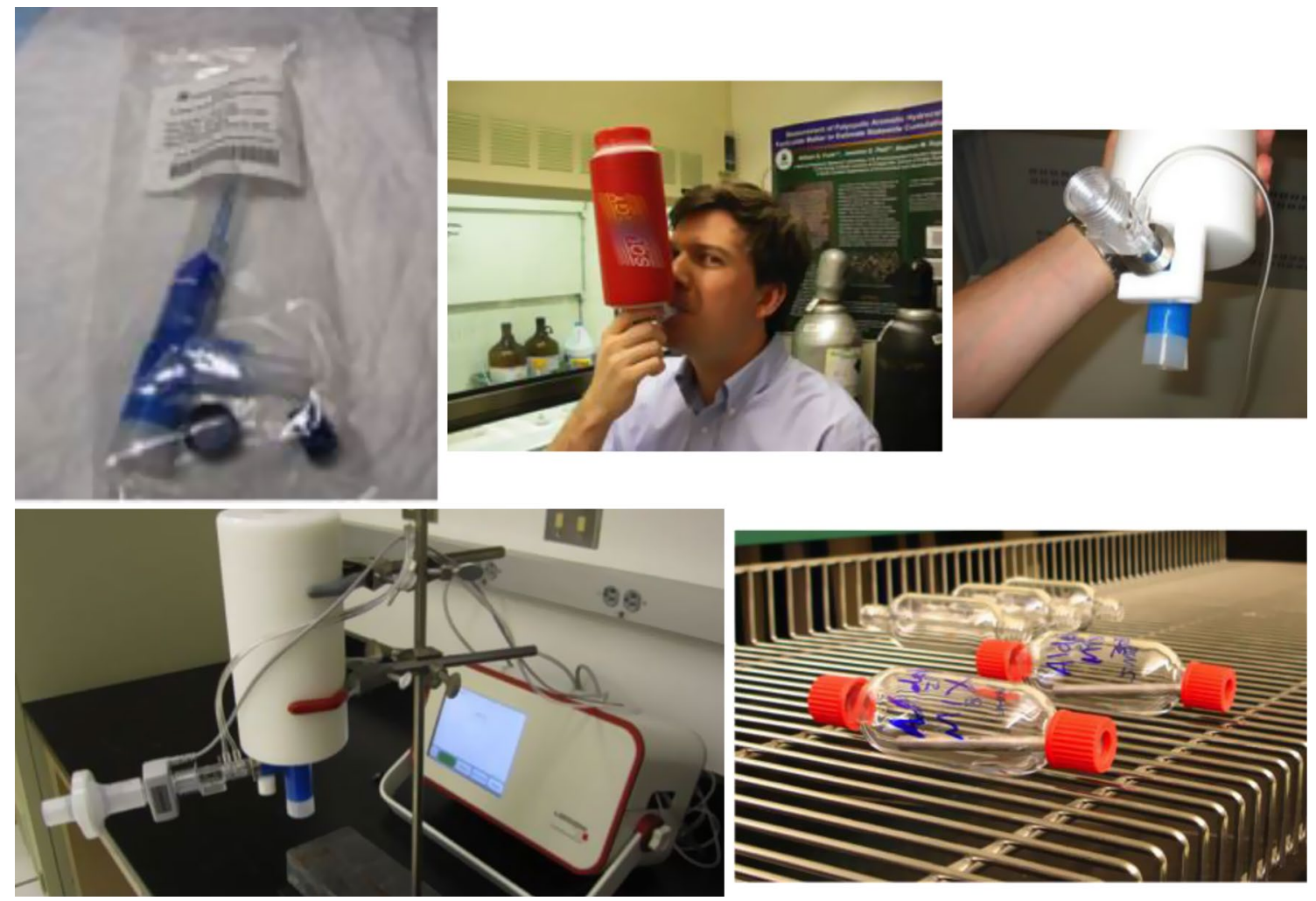

Fig. 3 Collection of EBC and EBA samples: standard "R-tube" kit for $\mathrm{EBC}$ (upper left); manual $\mathrm{EBC}$ collection with dry ice coolant (top center); automated feedback-controlled EBC and EBA collection

for routine collection of EBC. In our laboratory, for example, we use hardware from Respiratory Research, Austin TX, and instruments and methods modified to exploit chilled tube collection as from Loccioni Gruppa, Santa Rosario, Italy (Liu et al. 2007; Pleil et al. 2008; Soyer et al. 2006) as illustrated in Fig. 3. EBA is a subset of EBC and is extracted from total EBC, or collected directly using filter materials or particle impingers to capture bacteria, protein fragments, cell fragments, and other particulates directly and exclude gases and vapors (Holmgren et al. 2010; Horvath et al. 2005). EBC is a versatile medium; depending upon the goal of the study, polar volatile compounds can be analyzed by GC-MS, by liquid chromatography-mass spectrometry (LC-MS), or by various large molecules methods such as immunochemistry. EBC and EBA provide additional value in that they give access to the semi- and non-volatile constituents in breath for applications such as:

- Testing airway $\mathrm{pH}$ in liquid EBC for airway viscosity, asthma status, and other preclinical disease indicators.

- Assaying exhaled biomarkers of pulmonary inflammation (e.g., cytokines) in EBC or EBA with immunochemistry assays. using Loccioni device (top right and lower left); Tenax tube collection of polar VOCs from 1-ml EBC samples

- Collecting EBC for noninvasive genotyping of the pulmonary microbiome.

- Collecting EBC for developing ex vivo cultures of individual strains of pulmonary bacteria for VOCs fingerprinting via GC-MS.

- Assaying polar organic materials dissolved in water aerosol that are otherwise lost in gas-phase analyses via GC-MS or LC-MS.

- Assaying partition of non-volatile constituents (e.g., PM 2.5) that indicate previously inhaled particulate matter via LC-MS or immunochemistry.

Investigations of EBC and EBA are relatively new, especially for toxicological purposes. However, they do provide a noninvasive window into the larger non-volatile biomarkers and bioindicators previously thought to be accessible only through blood or urine, and also to polar organic and inorganic compounds difficult to assay using only the gas phase of breath (Hunt 2002).

\section{Toxicological applications for breath analysis}

Essentially, all blood, breath, and urine biomonitoring applications link to toxicology in some way. More 
specifically, the following breath-based topics have emerged as important in the past years and will be the focus of this review:

- Evaluation of smoking activity and toxic compounds.

- Interpreting the human exposome using case-control and community toxicity discovery approaches.

- Development of toxicokinetic models (ADME).

- Development of adverse outcome pathways (AOPs) and linking in vitro test to in vivo effects.

- Pulmonary function and inflammatory response.

- In vivo testing with isotopically labeled tracer compounds.

- Cell line testing for chemical toxicity prioritization.

As mentioned above, breath biomonitoring has advantages from multiple logistical perspectives. This is especially valuable for the regime of population-based monitoring, wherein one needs series of temporal or spot samples from a large number of people (or cell lines in petri dishes) (Cao and Duan 2006; Lin et al. 2005; Filipiak et al. 2010). Secondly, the use of gas-phase versus liquid-phase analysis provides advantage for high-throughput efficiency, especially with modern real-time instrumentation, wherein analyses can be multiplexed both longitudinally and in parallel with a single analytical platform (Smith and Španel 2005).

With few exceptions, the newer applications using EBC and EBA require some form of liquid-based analysis, which is more time- and labor-intensive; however, the logistical sampling advantages remain as opposed to bronchoalveolar lavage (Jackson et al. 2007). In contrast to blood and urine collection, one can still collect breath EBC and EBA samples without extensively trained personnel, without special infrastructure (clinic, bathroom, coolers) and without creating biohazardous wastes.

The topics presented in the ensuing text are certainly not all-inclusive because the breath research field and the study of toxicology are each enormously complex and expanding rapidly. However, this review provides a relatively broad overview of breath-based applications for toxicology within the context of contemporary use. Due to the breadth of this topic, a best effort is made to draw example references from classical articles and contemporary research; these should not be considered an exhaustive list.

\section{Current applications}

\section{Toxicity of smoking}

Historically, the earliest breath-based assessments of exogenous compounds toxicity revolved around tobacco smoking and specific compounds including carbon monoxide (CO), nitric oxide (NO), benzene, as well as a variety of other chemicals known to be associated with adverse health outcomes. (Jarvis et al. 1980; Kharitonov et al. 1995; Wester et al. 1986a, b, 1987a, b, c; Gordon et al. 1995; Gordon 1990). To date, smoking status is often used as a major factor in the validation of new technologies for breath analyses as it is well known that toxicity markers of all sorts should be differentiated in smokers versus nonsmokers (Santini et al. 2016; Kushch et al. 2008; Basanta et al. 2010; Španel and Smith 1996).

More recently, smoking status has been considered to be more of a confounder for diagnostic breath analysis, rather than the object of toxicity testing. In fact, many studies now deliberately exclude smokers or at least categorize them as a separate cohort to avoid erroneous correlations with disease diagnosis. This factor and other confounders have posed challenges for developing preclinical lung cancer diagnostics as it is difficult to find a large enough "never-smoker" control group of lung cancer patients, and it has been suggested that such patients actually suffer from a different type of cancer than do smokers (Kischkel et al. 2010; Sun et al. 2007).

\section{Exposome: case-control (non-targeted/discovery analysis)}

Traditional toxicological and pharmacological practice has generally implemented the targeted case-control study, wherein the initiating event is controlled, and the outcome is observed. Researchers split the subject pool into two groups; one group gets the chemical or drug, the other a placebo, and they wait to see the outcome. For toxicology, the groups are often rats or mice, and in pharmacology, they could be humans as well, once the drug reaches clinical trial status. Similarly, in classical environmental and epidemiological studies, subjects may be sorted by exposure category, say urban versus rural, farmer versus office worker, male versus female, etc., but again, the exposure is targeted a priori for observing the groups, for example automobile exhaust, pesticides, or consumer products, respectively (Rappaport 2012).

The new emerging technology for identifying toxicological effects of chemicals, especially those present in the environment, comprises the concept of "non-targeted" or "discovery" analysis (Pleil and Stiegel 2013; Rager et al. 2016). Here, there is no preconception as to which chemicals are associated with health outcome. The underlying mechanism is still some form of case-control comparison, but now the analytical strategy is to measure all possible chemicals, and try to discover empirically which differentiate the groups. This research revolves around the concept of the human exposome proposed in 2005 by Christopher Wild, Director 
of the International Agency of Research on Cancer (IARC, Lyon, France). The exposome represents the totality of chemical space in human media, both from environmental and internal metabolism sources and, as such, is thought to embody the chemical record of human environment interaction (Wild 2005; Rappaport 2011; Pleil 2012). An outcome of this model is the newest concept, the environmental-wide association study (EWAS), wherein the standard case-control framework is opened up to mining of bigger databases (Patel et al. 2010; Rappaport et al. 2014).

Exhaled breath, and especially the EBC fraction, has joined blood and urine as a primary biological fluid expressing the human exposome. There are three classes of toxicological stressors that are preferentially accessible in breath:

- volatile organics (both exogenous and endogenous),

- inflammatory markers, proteins, and inorganic particulates,

- pulmonary bacteria, viruses, and their associated toxins.

All of these classes represent some portion of the human exposome and can be used for disease and toxicity diagnoses. For example, patterns discovered in cytokines, polar volatile organics, fine particles, aerosols, and bacterial off-gas products have been used to establish "what is unremarkable" so that outlier effects could also be detected (Stiegel et al. 2015; Hubbard et al. 2009; Benor et al. 2015; Moritz et al. 2015; Greguš 2015).

\section{Toxicokinetics}

The first kinetics applications for breath biomarkers in toxicology actually evolved from medical anesthesiology. These approaches implemented absorption, distribution, metabolism, and excretion (ADME) of volatile anesthetics such as isoflurane, enflurane, and halothane (Fiserova-Bergerova and Holaday 1979). Breath analysis tools are still in use for assessing the progression of anesthesia and evaluation of organ function. (Miekisch et al. 2008; Ghimenti et al. 2013; Lirk et al. 2004). Breath ADME approaches have been extended to exploring toxicity of exogenous VOCs by determining the rate constants of uptake and elimination for suites of compounds implicated in human carcinogenicity including chloroform, benzene, methyl tertiary butyl ether, toluene, naphthalene, vinyl chloride, carbon tetrachloride, trichloroethylene, dichlorobenzene (Pellizzari et al. 1992; Pleil and Lindstrom 1997; Pleil et al. 2007). As the rate constants in the first compartment (blood) reflect half-times of 0.5-2 min, only high-frequency collection of breath samples could keep up (Gordon et al. 1988; Chinery and Gleason 1993; Pleil and Lindstrom 1998; Ashley et al. 1996).
The ability to take fast measurements to assess temporal uptake and elimination profiles from controlled breath studies is crucial for interpreting steady-state blood/breath partitions, minimum dose, and multiple-compartment capacities (Buckley et al. 1997; Dobrev et al. 2001; Wallace et al. 1993). All of these parameters are crucial for assessing toxicological properties of important environmental and occupational organics. Furthermore, it was the toxicological applications that fostered the new technologies of real-time mass-based instruments including proton transfer reaction mass spectrometry (PTR-MS), ion mobility spectrometry (IMS), and selected ion flow tube mass spectrometry (SIFT-MS) (Lindinger et al. 1998; Baumbach and Eiceman 1999; Smith and Španel 2005).

In addition to developing kinetic parameters for use in toxicokinetic models, there are other toxicological applications that rely on rapid breath assessments based on a variety of chemical, optical, and mass-based sensors. Some examples are ingestion of volatile foods or substances (Beauchamp et al. 2010; Traucher et al. 1996), breath diagnosis of life-threatening hydrogen cyanide (HCN) toxicity in victims of fire (Stamyr et al. 2015), alcohol and ethylene glycol poisoning (Johanson 2000; Walsh and Macleod 1983; Eder et al. 1998), carbon monoxide exposures (Cunnington and Hormbrey 2002), and toluene abuse (Garriott et al. 1981).

\section{Adverse outcome pathways (AOPs)}

The concept of the AOP as a mechanism for high-throughput toxicity testing is relatively new. The general idea is that the toxicological impact of an exogenous chemical exposure is initiated in the human systems biology and then creates a cascade of subsequent events (typically at the molecular or cellular level) that ultimately lead to an adverse preclinical or clinical outcome (Adeleye et al. 2015; Pleil et al. 2015; Tollefsen et al. 2014). Once an AOP is established from in vivo laboratory study, one small section of the chemical reaction chain is reproduced in vitro to represent the full pathway. To date, AOP tests are mostly implemented in multi-well plates and the analyses are based on liquid-phase immunochemistry, although some liquid chromatography work may also be performed (Kavlock et al. 2012; Parker et al. 2000; Inglese et al. 2007). A complementary approach has been proposed termed the aggregate exposure pathway (AEP), which is meant to serve as the precursor analog to the AOP (Teeguarden et al. 2016).

Neither AOP nor AEP approaches have as yet been implemented using breath-based toxicity testing. However, recently, the concept of "cell breath" has been proposed that would complement standard liquid-phase high-throughput toxicity testing with a headspace gas component (Pleil 2016). The use of gas-phase probes has a number of advantages. Analyses could be multiplexed longitudinally as the 
sample is not consumed as in liquid testing. Gas-phase analyses using real-time instrumentation are extremely fast, typically less than a second or so per data point, and can be highly specific and diagnostic if coupled with high-resolution mass spectrometry (Smith and Španel 2011; Pleil and Isaacs 2016). Certain metabolic pathways that have been characterized in vivo could be probed directly in vitro or ex vivo in a gas-phase analog of liquid-phase AOP testing (Angrish et al. 2015). Finally, the use of cellular respiration analysis provides a platform for direct toxicity testing of gas-phase toxicants, which is currently lacking for highthroughput testing.

\section{Pulmonary function}

Breath-based toxicity research does not necessarily require chemical biomarker analysis. One of the simplest methods for assessing the immediate toxic effects of exogenous (airborne) exposures or onset of pulmonary disease flare-up is a change in lung function (Penttinen et al. 2001; Madden et al. 2014). Although not a traditional chemical biomarker, a physiological marker is just as useful in assessing a perturbation (Pleil 2012). Here, the analytical finish is a straightforward measurement of exhaled volume, speed, and in some cases temperature (Lázár et al. 2014). The primary parameters are $\mathrm{FEV}_{1}$, the total volume of breath forcefully expelled in the first second, and FVC, the forced vital capacity or the maximum expiratory volume of a single breath, although a variety of other parameters have been used as well (Morris 1976). Both are very sensitive to pulmonary inflammation from asthma condition, chronic obstructive pulmonary disease (COPD), and air pollution, as well as interactions among them (Harving et al. 1991; Mannino et al. 2003; Scannell et al. 1996; Liu et al. 2009). This can be a large and noticeable effect; a number of studies have shown that chronic urban exposures to traffic and ozone can reduce pulmonary function by approximately 5-25\% (Götschi et al. 2008) and that acute co-exposures to urban levels of ozone and diesel exhaust can synergistically induce reductions in pulmonary function of about $17 \%$ on average (Madden et al. 2014). Certainly, pulmonary function tests alone are not definitive for specific identifying causes; complementary measures of breath-borne inflammatory markers, exogenous compounds, and endogenous volatiles are required to establish toxic effects.

\section{Isotopically labeled tracer compounds}

The toxicity of exogenous compounds often depends on the particular human metabolic pathway or microbiome interaction that is affected in different ways based on an individual person's genotype or phenotype; compounds can experience variability in detoxification for excretion, or their metabolites could become more toxic than the original compounds are alone (Bugrim et al. 2004; Thomas et al. 2001; Savides and Oehme 1983; Clayton et al. 2009). Standard procedures in pharmacology and toxicology generally rely on identifying metabolites in blood or excreted in urine to establish the metabolic paths, and then retrospective analysis is used to interpret genetic polymorphisms or phenotype that influence these outcomes. The ultimate goal is to interpret genomic patterns and epigenetic modifications to identify individuals at risk and provide advice on drug prescription or intervention/avoidance of certain environmental or commercial chemicals (Shimada et al. 1994; Easton et al. 2007; Baccarelli and Bollati 2009).

Exhaled breath and EBC tests have become an important feature in the realm of individualized or personalized medicine and toxicity testing (Modak 2010, 2013; Baraldi et al. 2009; Fens et al. 2009). However, rather than taking complex genetic and metabolite measurements, new breath tests now rely on specific probe molecules and the subsequent appearance of exhaled compounds like carbon dioxide $\left(\mathrm{CO}_{2}\right)$, oxygen $\left(\mathrm{O}_{2}\right)$, or hydrogen $\left(\mathrm{H}_{2}\right)$. Most of the novel tests employ organic compounds with isotopically labeled carbon-13 $\left({ }^{13} \mathrm{C}\right)$, oxygen-18 $\left({ }^{18} \mathrm{O}\right)$, or deuterium $\left({ }^{2} \mathrm{H}\right)$, wherein a more complex organic probe molecule with these substitutions is injected into or ingested by the patient (Schellekens et al. 2011). Exhaled breath is then monitored using mass spectrometry or optical instrumentation for perturbations in the normal isotopic abundances of water or $\mathrm{CO}_{2}$ that would indicate metabolism of the probe (Smith et al. 2002; Crosson et al. 2002; Logan et al. 1991). Of particular note in this category is the helicobacter pylori $\mathrm{CO}_{2}$ breath test based on ingestion of ${ }^{13} \mathrm{C}$-labeled urea, which has become a standard noninvasive alternative method for identifying an underlying cause of gastric and duodenal ulcers (Cutler et al. 1995).

From a chemical toxicological perspective, an important development for isotopic breath tests is personalized testing of chemotherapeutic agents (Polk and Peek 2010). Chemotherapy is designed to be more cytotoxic for cancer than human cells; however, there are individual genotypes for which this distinction is not sufficient. In fact, in some individuals, the treatment could prove fatal. Rather than inferring metabolism paths from detailed genetic testing, the patient is given a benign surrogate that is isotopically labeled, and then, the metabolism pathway is directly monitored via an exhaled gas, typically ${ }^{13} \mathrm{C}$-labeled $\mathrm{CO}_{2}$ (Modak 2007). For example, cancer patients are treated with ${ }^{13} \mathrm{C}$-labeled methionine to assess mitochondrial toxicity of antiretroviral drugs (Milazzo et al. 2005), or with $\left[{ }^{13} \mathrm{C}\right]$-dextromethorphan to assess breast cancer therapy with tamoxifen (Opdam et al. 2015). A variety of chemical probes including $\left[{ }^{13} \mathrm{C}\right]$-dextromethorphan, $\left[{ }^{13} \mathrm{C}\right]-$ pantoprazole, and $\left[{ }^{13} \mathrm{C}\right]$-uracil have been used to evaluate 
activity of CYP2D6, CYP2C19, and DPD enzymes, which are important in about $35 \%$ of FDA-approved medications (Modak 2009). As such, a simple 1-hour spot test of exhaled ${ }^{13} \mathrm{C}$-labeled carbon dioxide can establish specific enzymatic pathways without the effort and cost of genotyping or measuring a suite of metabolites.

\section{In vitro to in vivo linkage; cell line toxicity prioritization tests}

As mentioned above in the AOPs discussion, the implementation of cellular level respiration analysis has offered a new opportunity for linking chemical toxicity at the systemic (in vivo) level to a more pragmatic set of test performed in cell line bioreactors (Astashkina et al. 2012; Bhogal et al. 2005). This approach is currently relegated to liquid analysis (Dix et al. 2007; Soldatow et al. 2013); the ultimate breath (or cell breath) applications are still in their infancy, but are currently under laboratory development as a complementary technique.

The current focus for "cell breath" research is to measure volatile emissions from bacterial mono-cultures to identify patterns of VOCs in vitro and develop a "fingerprint" library (Shestivska et al. 2015; Zhu et al. 2013; Sethi et al. 2013). Subsequently, measurements of human exhaled breath could be explored for such patterns to diagnose infectious state and monitor treatment (Risby and Solga 2006; Barker et al. 2006; Christ-Crain and Müller 2007). These investigations do not have direct toxicological implications; however, they have provided the underlying technology for maintaining viable cell cultures and measuring gas-phase chemicals. The ultimate goal for toxicity testing is to use this technology to probe for changes in the baseline respiration patterns of cell cultures (bacterial, animal, human) upon administration of potentially toxic substances. The magnitude of the observed perturbations in vitro could be compared to the applied dose to prioritize chemicals for more detailed in vivo toxicity testing to complement current high-throughput tests at the molecular level (Judson et al. 2010; Tice et al. 2013).

\section{Future applications}

A number of future applications for breath biomarkers in toxicology have been alluded to above. These mostly involve novel collection methods, implementation of aerosol diagnostics, and new technologies for rapid measurement of cellular-based media. Briefly, they are encapsulated by these topics:

- Breath spot analysis

- Miniaturized bioreactors
- Microbiome interaction

- Crowd breath

\section{Breath spot}

The clinical/medical communities have long embraced the concept of the dried blood spot (DBS), or "Guthrie spot," as a convenient medium for specific screening tests for childhood metabolic diseases (Guthrie and Susi 1963; Garrick et al. 1973; Crossle et al. 1979). More recently, archived and new DBS media have been tested for metals and chemicals in newborns that could be indicative of prenatal exposures or used to monitor drug dose (Spliethoff et al. 2008; Funk et al. 2015; Spooner et al. 2009). Neonatal DBS have also been used to assess inflammatory markers and growth factors and are considered new tools for case-control disease studies (Skogstrand et al. 2005). Based on these concepts, the next logical step is to implement the analog "dried breath spot" or DBrS (to differentiate it from DBS). The concept is to have subjects exhale through a standard disposable respiratory filter as used in spirometry, which would capture aerosols, bacteria, cell fragments, and large molecules carried by vapor. Upon air-drying, these could easily be shipped to a laboratory for extraction and analysis of captured analytes. For now, this is speculative, but could well become a very simple toxicological assessment tool especially for population-based studies where simplicity in the field is paramount.

\section{Miniaturized bioreactor}

Growing and maintaining viable cell lines ex vivo is a difficult endeavor. Commercial bioreactors used for cell and tissue cultures are fairly large (liter to $\mathrm{m}^{3}$ volumes), and even the term "mini-bioreactor" refers to volumes of $100 \mathrm{ml}$ or so (Marks 2003; Kumar et al. 2004). As cells and tissues require constant gas and nutrient flows, it is possible to monitor processes via online analysis (Matz and Lennemann 1996; Luchner et al. 2012). Such largescale processes, however, are not amenable to toxicity testing, and so standard AOP-based methods are implemented in microwell arrays (typically 96-well plates) and condensed-phase (liquid) analysis. The challenges for implementing microscale gas analysis are sensitivity and speed as volumes encountered therein are of the order of microliters $(\mu l)$ and current systems for gas analyses need milliliter (ml) volumes. However, the advances in chemical array sensors, mid-infrared laser spectrometers, and bench-top time of flight mass spectrometers (ToF-MS) hold promise in approaching the needs of real-time gasphase analysis at the microscale, and some progress is being made for these applications (Baranska et al. 2015; Filipiak et al. 2015). 


\section{Microbiome interaction}

Human cells are not unique in experiencing toxic effects from exogenous chemicals. The human microbiome represents about 10 times as many bacterial cells as those comprising an adult person (Sleator 2010). As such, the human exposome can be affected by direct bacterial metabolism of toxic chemicals, especially in the gut and lung, where exogenous exposures are most likely (Possemiers et al. 2009). Recent research has shown that certain toxicity pathways are activated by the microbiome, whereas human cells would otherwise be unaffected. A well-known example is the gut bacterial metabolic product l-carnitine, linked to cardiovascular disease, which occurs only in subjects who are regular meat eaters, but not vegetarians (Ussher et al. 2013). Diagnostic pattern analysis of cell breath, both in vivo and ex vivo, of the human microbiome as a source of toxic metabolism has the potential for developing antibiotic intervention treatments.

\section{Crowd breath}

At the opposite end of the philosophical spectrum from in vitro cellular respiration of monocultures is a new concept for using breath biomarkers in toxicology. Termed "crowd breath," this is a non-targeted (discovery) approach, wherein the air surrounding crowds of people is repeatedly analyzed to develop a time course of as many organic molecules as possible (Williams and Pleil 2016). These samples represent a mixture of sources from the surrounding environment, commercial and personal products, local industrial emissions, as well as from human breath. To separate out the aggregate breath source, compounds are sorted by co-variance with known breath emissions of acetone, isoprene, and $\mathrm{CO}_{2}$. This technique was applied to monitoring people inside a movie theater, and the results were annotated with specific scenes that could arouse emotion, e.g., fear, humor, suspense, stress (Williams et al. 2016). The ultimate value for toxicological research would be linking microenvironmental contaminants back to exhaled breath to assess group exposures, and possibly health risk levels. Another potential use would be to evaluate the toxicological potential of non-chemical stressors (emotion) via endogenous breath markers emitted by groups.

\section{Summary}

Environmental health and clinical practice have embraced many of the concepts of breath biomarker testing for practical reasons: Breath testing is noninvasive and strategically straightforward, and samples are essentially limitless. These qualities have made breath a valuable complement to standard toxicological investigations using blood and urine samples. Breath has also carved a niche as a simple "stand-alone" sampling medium, especially when rapid sampling frequency is needed in the case of toxicokinetic studies. Furthermore, human breath investigations are no longer relegated to just the gas phase; the condensate and aerosol fractions of exhalations are now routinely used to gain access to protein fragments, microbiological media, dissolved inorganics, and highly polar compounds. Breath samples give immediate access to monitoring specific metabolism pathways indicative of toxicity by the use of pattern "fingerprinting" or isotopically labels probes. And finally, the broad field of breath analysis is now expanding to the arena of "cell breath" where individual strains of cells, bacteria, or tissue samples are explored, all the way to "crowd breath" where groups of individuals are tested for more generic toxicological responses.

Acknowledgments The author is grateful for many interesting and thought-provoking discussions with friends and colleagues in the breath research and toxicology communities over the years. These include (but are not limited to): Terence Risby from Johns Hopkins University, Baltimore MD, USA; Jens Herbig from Ionicon Analytik, Innsbruck, Austria; Jonathan Beauchamp from Fraunhofer Institute, Freising, Germany; Anil Modak from Cambridge Isotope Laboratories, Cambridge MA, USA; Michael Madden, Ariel Wallace, Michelle Angrish, Jon Sobus, Andrew Lindstrom, Andrew Ghio, and Lance Wallace (ret.) from US EPA, Research Triangle Park, NC, USA; David Smith from Keele University, Stoke-on-Trent, UK; Patrik Spanel from Heyrovsky Institute, CZ; Jane Hill from Dartmouth College, Hanover, NH, USA; Cristina Davis from University of California, Davis, CA, USA; Stephen Rappaport from University of California, Berkeley, USA; Matthew Stiegel from Duke University, Durham NC, USA; Wolfram Miekisch and Jochen Schubert from Medical University of Rostock, Germany; Fabio DiFrancesco from University of Pisa, Italy; Jonathan Williams from Max Planck Institute, Mainz, Germany; and the late Anton Amann (passed in 2016) from Innsbruck Medical University, Austria, a great friend and mentor who ushered breath research into the twenty-first century by founding the International Association of Breath Research (IABR) and the Institute of Physics Journal of Breath Research (JBR).

\section{References}

Adeleye Y, Andersen M, Clewell R, Davies M, Dent M, Edwards S, Fowler P, Malcomber S, Nicol B, Scott A, Scott S (2015) Implementing toxicity testing in the twenty-first century (TT21C): making safety decisions using toxicity pathways, and progress in a prototype risk assessment. Toxicology 332:102-111

Almstrand AC, Ljungström E, Lausmaa J, Bake B, Sjövall P, Olin AC (2008) Airway monitoring by collection and mass spectrometric analysis of exhaled particles. Anal Chem 81(2):662-668

Amann A, Smith D (eds) (2005) Breath analysis for clinical diagnosis and therapeutic monitoring. World Scientific Publishing Co., Singapore

Amann A, de Lacy CB, Miekisch W, Schubert J, Buszewski B, Pleil JD, Ratcliffe N, Risby TH (2014a) The human volatilome: volatile organic compounds (VOCs) in exhaled breath, skin emanations, urine, feces and saliva". J Breath Res 8:034001 
Amann A, Mochalski P, Ruzsanyi V, Broza YY, Haick H (2014b) Assessment of the exhalation kinetics of volatile cancer biomarkers based on their physicochemical properties. J Breath Res 8(1):016003

Angrish MM, Madden MC, Pleil JD (2015) Probe molecules (PrM) approach in adverse outcome pathway (AOP) based high throughput screening (HTS): in vivo discovery for developing in vitro target methods. Chem Res Toxicol 28(4):551-559

Arasaradnam RP, McFarlane M, Ling K, Wurie S, O'Connell N, Nwokolo CU, Bardhan KD, Skinner J, Savage RS, Covington JA (2016) Breathomics-exhaled volatile organic compound analysis to detect hepatic encephalopathy: a pilot study. J Breath Res 10(1):016012

Ashley DL, Bonin MA, Cardinali FL, McCraw JM, Wooten JV (1996) Measurement of volatile organic compounds in human blood. Environ Health Perspect 104(Suppl 5):871-877

Astashkina A, Mann B, Grainger DW (2012) A critical evaluation of in vitro cell culture models for high-throughput drug screening and toxicity. Pharmacol Ther 134(1):82-106

Baccarelli A, Bollati V (2009) Epigenetics and environmental chemicals. Curr Opin Pediatr 21(2):243-251

Baraldi E, Carraro S, Giordano G, Reniero F, Perilongo G, Zacchello F (2009) Metabolomics: moving towards personalized medicine. Ital J Pediatr 35:30

Baranska A, Smolinska A, Boots AW, Wallinga JW, van Schooten FJ (2015) Dynamic collection and analysis of volatile organic compounds from the headspace of cell cultures. J Breath Res 9:047102

Barker M, Hengst M, Schmid J, Buers HJ, Mittermaier B, Klemp D, Koppmann R (2006) Volatile organic compounds in the exhaled breath of young patients with cystic fibrosis. Eur Respir $\mathbf{J}$ 27(5):929-936

Basanta M, Jarvis RM, Xu Y, Blackburn G, Tal-Singer R, Woodcock A, Singh D, Goodacre R, Thomas CP, Fowler SJ (2010) Non-invasive metabolomic analysis of breath using differential mobility spectrometry in patients with chronic obstructive pulmonary disease and healthy smokers. Analyst 135(2):315-320

Baumbach J, Eiceman G (1999) Ion mobility spectrometry: arriving on-site and moving beyond a low profile. Appl Spectros $53: 338-354$

Beauchamp J (2011) Inhaled today, not gone tomorrow: pharmacokinetics and environmental exposure of volatiles in exhaled breath. J Breath Res 5(3):037103

Beauchamp J, Kirsch F, Buettner A (2010) Real-time breath gas analysis for pharmacokinetics: monitoring exhaled breath by on-line proton-transfer-reaction mass spectrometry after ingestion of eucalyptol-containing capsules. J Breath Res 4(2):026006

Benor S, Alcalay Y, Domany KA, Gut G, Soferman R, Kivity S, Fireman E (2015) Ultrafine particle content in exhaled breath condensate in airways of asthmatic children. J Breath Res 9(2):026001

Bhogal N, Grindon C, Combes R, Balls M (2005) Toxicity testing: creating a revolution based on new technologies. Trends Biotechnol 23(6):299-307

Buckley TJ, Prah JD, Ashley D, Zweidinger RA, Wallace LA (1997) Body burden measurements and models to assess inhalation exposure to methyl tertiary butyl ether (MTBE). J Air Waste Manag Assoc 47(7):739-752

Bugrim A, Nikolskaya T, Nikolsky Y (2004) Early prediction of drug metabolism and toxicity: systems biology approach and modeling. Drug Discov Today 9(3):127-135

Cao W, Duan Y (2006) Breath analysis: potential for clinical diagnosis and exposure assessment. Clin Chem 52(5):800-811

Cao W, Duan Y (2007) Current status of methods and techniques for breath analysis. Crit Rev Anal Chem 37(1):3-13
Chinery RL, Gleason AK (1993) A compartmental model for the prediction of breath concentration and absorbed dose of chloroform after exposure while showering. Risk Anal 13(1):51-62

Christ-Crain M, Müller B (2007) Biomarkers in respiratory tract infections: diagnostic guides to antibiotic prescription, prognostic markers and mediators. Eur Respir J 30(3):556-573

Clayton TA, Baker D, Lindon JC, Everett JR, Nicholson JK (2009) Pharmacometabonomic identification of a significant hostmicrobiome metabolic interaction affecting human drug metabolism. Proc Natl Acad Sci 106(34):14728-14733

Crossle J, Elliot RB, Smith P (1979) Dried-blood spot screening for cystic fibrosis in the newborn. Lancet 313(8114):472-474

Crosson ER, Ricci KN, Richman BA, Chilese FC, Owano TG, Provencal RA, Todd MW, Glasser J, Kachanov AA, Paldus BA, Spence TG (2002) Stable isotope ratios using cavity ring-down spectroscopy: determination of $13 \mathrm{C} / 12 \mathrm{C}$ for carbon dioxide in human breath. Anal Chem 74(9):2003-2007

Cunnington AJ, Hormbrey P (2002) Breath analysis to detect recent exposure to carbon monoxide. Postgrad Med J 78(918):233-237

Cutler AF, Havstad S, Ma CK, Blaser MJ, Perez-Perez GI, Schubert TT (1995) Accuracy of invasive and noninvasive tests to diagnose Helicobacter pylori infection. Gastroenterology 109(1):136-141

Dix DJ, Houck KA, Martin MT, Richard AM, Setzer RW, Kavlock RJ (2007) The ToxCast program for prioritizing toxicity testing of environmental chemicals. Toxicol Sci 95(1):5-12

Dobrev ID, Andersen ME, Yang RS (2001) Assessing interaction thresholds for trichloroethylene in combination with tetrachloroethylene and 1,1,1-trichloroethane using gas uptake studies and PBPK modeling. Arch Toxicol 75(3):134-144

Droz PO, Guillemin MP (1986) Occupational exposure monitoring using breath analysis. J Occup Environ Med 28(8):593-602

Dubowski KM (1974) Breath analysis as a technique in clinical chemistry. Clin Chem 20(8):966-972

Easton DF, Pooley KA, Dunning AM, Pharoah PD, Thompson D, Ballinger DG, Struewing JP, Morrison J, Field H, Luben $\mathrm{R}$, Wareham N (2007) Genome-wide association study identifies novel breast cancer susceptibility loci. Nature 447(7148):1087-1093

Eder AF, McGrath CM, Dowdy YG, Tomaszewski JE, Rosenberg FM, Wilson RB, Wolf BA, Shaw LM (1998) Ethylene glycol poisoning: toxicokinetic and analytical factors affecting laboratory diagnosis. Clin Chem 44(1):168-177

Fens N, Zwinderman AH, van der Schee MP, de Nijs SB, Dijkers E, Roldaan AC, Cheung D, Bel EH, Sterk PJ (2009) Exhaled breath profiling enables discrimination of chronic obstructive pulmonary disease and asthma. Am J Respir Crit Care Med 180(11):1076-1082

Filipiak W, Sponring A, Filipiak A, Ager C, Schubert J, Miekisch W, Amann A, Troppmair J (2010) TD-GC-MS analysis of volatile metabolites of human lung cancer and normal cells in vitro. Cancer Epidemiol Biomark Prev 19(1):182-195

Filipiak W, Filipiak A, Sponring A, Schmid T, Zelger B, Ager C, Klodzinska E, Denz H, Pizzini A, Lucciarini P, Jamnig H, Troppmair J, Amann A (2014) Comparative analyses of volatile organic compounds (VOCs) from patients, tumors and transformed cell lines for the validation of lung cancer-derived breath markers. J Breath Res 8(2):027111

Filipiak W, Beer R, Sponring A, Filipiak A, Ager C, Schiefecker A, Lanthaler S, Helbok R, Nagl M, Troppmair J, Amann A (2015) Breath analysis for in vivo detection of pathogens related to ventilator-associated pneumonia in intensive care patients: a prospective pilot study. J Breath Res 9:016004

Fiserova-Bergerova V, Holaday DA (1979) Uptake and clearance of inhalation anesthetics in man. Drug Metab Rev 9(1):43-60 
Fridman GY, Tang H, Feller-Kopman D, Hong Y (2015) MouthLab: a tricorder concept optimized for rapid medical assessment. Ann Biomed Eng 43(9):2175-2184

Funk WE, Pleil JD, Sauter DJ, McDade TW, Holl JL (2015) Use of dried blood spots for estimating children's exposures to heavy metals in epidemiological research. J Environ Anal Toxicol S7:002. doi:10.4172/2161-0525

Garrick MD, Dembure P, Guthrie R (1973) Sickle-cell anemia and other hemoglobinopathies: procedures and strategy for screening employing spots of blood on filter paper as specimens. N Engl J Med 288(24):1265-1268

Garriott JC, Foerster E, Juarez L, De la Garza F, Mendiola I, Curoe J (1981) Measurement of toluene in blood and breath in cases of solvent abuse. Clin Toxicol 18(4):471-479

Ghimenti S, Di Francesco F, Onor M, Stiegel MA, Trivella MG, Comite C, Catania N, Fuoco R, Pleil JD (2013) Post-operative elimination of sevoflurane anesthetic and hexafluoroisopropanol metabolite in exhaled breath: pharmacokinetic models for assessing liver function. J Breath Res 7(3):036001

Gordon SM (1990) Identification of exposure markers in smokers' breath. J Chromatogr A 11:291-302

Gordon SM, Wallace LA, Pelllzzari ED, O’Neill HJ (1988) Human breath measurements in a clean-air chamber to determine half-lives for volatile organic compounds. Atmos Environ 22(10):2165-2170

Gordon SM, Wallace LA, Brinkman MC, Callahan PJ, Kenny DV (1995) Volatile organic compounds as breath biomarkers for active and passive smoking. Environ Health Perspect 110(7):689-698

Götschi T, Heinrich J, Sunyer J, Künzli N (2008) Long-term effects of ambient air pollution on lung function: a review. Epidemiology 19(5):690-701

Greguš M, Foret F, Kindlová D, Pokojová E, Plutinský M, Doubková M, Merta Z, Binková I, Skřičková J, Kubáň P (2015) Monitoring the ionic content of exhaled breath condensate in various respiratory diseases by capillary electrophoresis with contactless conductivity detection. J Breath Res 9(2):027107

Grob NM, Aytekin M, Dweik RA (2008) Biomarkers in exhaled breath condensate: a review of collection, processing and analysis. J Breath Res 2(3):037004

Guthrie R, Susi A (1963) A simple phenylalanine method for detecting phenylketonuria in large populations of newborn infants. Pediatrics 32(3):338-343

Harving H, Dahl R, Mølhave L (1991) Lung function and bronchial reactivity in asthmatics during exposure to volatile organic compounds. Am Rev Respir Dis 143:751-754

Holmgren H, Ljungström E, Almstrand AC, Bake B, Olin AC (2010) Size distribution of exhaled particles in the range from 0.01 to $2.0 \mu \mathrm{m}$. J Aerosol Sci 41(5):439-446

Horvath I, Hunt J, Barnes PJ (2005) Exhaled breath condensate: methodological recommendations and unresolved questions. Eur Respir J 26(3):523-548

Hubbard HF, Sobus JR, Pleil JD, Madden MC, Tabucchi S (2009) Application of novel method to measure endogenous VOCs in exhaled breath condensate before and after exposure to diesel exhaust. J Chromatogr B 877(29):3652-3658

Hunt J (2002) Exhaled breath condensate: an evolving tool for noninvasive evaluation of lung disease. J Allergy Clin Immunol 110(1):28-34

Inglese J, Johnson RL, Simeonov A, Xia M, Zheng W, Austin CP, Auld DS (2007) High-throughput screening assays for the identification of chemical probes. Nat Chem Biol 3(8):466-479

Jackson AS, Sandrini A, Campbell C, Chow S, Thomas PS, Yates DH (2007) Comparison of biomarkers in exhaled breath condensate and bronchoalveolar lavage. Am J Respir Crit Care Med 175(3):222-227
Jarvis MJ, Russell MA, Saloojee Y (1980) Expired air carbon monoxide: a simple breath test of tobacco smoke intake. Br Med J 281(6238):484-485

Jezierski T, Walczak M, Ligor T, Rudnicka J, Buszewski B (2015) Study of the art: canine olfaction used for cancer detection on the basis of breath odour, perspectives and limitations. J Breath Res 9(2):027001

Johanson G (2000) Toxicity review of ethylene glycol monomethyl ether and its acetate ester. Crit Rev Toxicol 30(3):307-345

Johnson GR, Morawska L (2009) The mechanism of breath aerosol formation. J Aerosol Med Pulm Drug Deliv 22(3):229-237

Judson RS, Houck KA, Kavlock RJ, Knudsen TB, Martin MT, Mortensen HM, Reif DM, Rotroff DM, Shah I, Richard AM, Dix DJ (2010) In vitro screening of environmental chemicals for targeted testing prioritization: the ToxCast project. Environ Health 118(4):485-492

Kavlock R, Chandler K, Houck K, Hunter S, Judson R, Kleinstreuer N, Knudsen T, Martin M, Padilla S, Reif D, Richard A (2012) Update on EPA's ToxCast program: providing high throughput decision support tools for chemical risk management. Chem Res Toxicol 25(7):1287-1302

Kharitonov SA, Robbins RA, Yates D, Keatings V, Barnes PJ (1995) Acute and chronic effects of cigarette smoking on exhaled nitric oxide. Am J Respir Crit Care Med 152(2):609-612

Kischkel S, Miekisch W, Sawacki A, Straker EM, Trefz P, Amann A, Schubert JK (2010) Breath biomarkers for lung cancer detection and assessment of smoking related effects-confounding variables, influence of normalization and statistical algorithms. Clin Chim Acta 411(21):1637-1644

Kumar S, Wittmann C, Heinzle E (2004) Review: minibioreactors. Biotechnol Lett 26(1):1-10

Kushch I, Schwarz K, Schwentner L, Baumann B, Dzien A, Schmid A, Unterkofler K, Gastl G, Španěl P, Smith D, Amann A (2008) Compounds enhanced in a mass spectrometric profile of smokers' exhaled breath versus non-smokers as determined in a pilot study using PTR-MS. J Breath Res 2(2):026002

Laleman I, Dadamio J, De Geest S, Dekeyser C, Quirynen M (2014) Instrumental assessment of halitosis for the general dental practitioner. J Breath Res 8(1):017103

Lázár Z, Bikov A, Martinovszky F, Gálffy G, Losonczy G, Horváth I (2014) Exhaled breath temperature in patients with stable and exacerbated COPD. J Breath Res 8(4):1046002

Lin YS, Kupper LL, Rappaport SM (2005) Air samples versus biomarkers for epidemiology. Occup Environ Med 62(11):750-760

Lindinger W, Hansel A, Jordan A (1998) Proton transfer reaction mass spectrometry (PTR-MS): on-line monitoring of volatile organic compounds at pptv levels. Chem Soc Rev 27:347-354

Lioy PJ, Rappaport SM (2011) Exposure science and the exposome: an opportunity for coherence in the environmental health sciences. Environ Health Perspect 119(11):A466

Lippmann M, Schlesinger RB (2000) Toxicological bases for the setting of health-related air pollution standards. Annu Rev Public Health 21(1):309-333

Lirk P, Bodrogi F, Rieder J (2004) Medical applications of proton transfer reaction-mass spectrometry: ambient air monitoring and breath analysis. Int J Mass Spectrom 239(2):221-226

Liu J, Conrad DH, Chow S, Tran VH, Yates DH, Thomas PS (2007) Collection devices influence the constituents of exhaled breath condensate. Eur Respir J 30(4):807-808

Liu L, Poon R, Chen L, Frescura AM, Montuschi P, Ciabattoni G, Wheeler A, Dales R (2009) Acute effects of air pollution on pulmonary function, airway inflammation, and oxidative stress in asthmatic children. Environ Health Perspect 117(4):668-674

Logan RP, Polson RJ, Misiewicz JJ, Rao G, Karim NQ, Newell D, Johnson P, Wadsworth J, Walker MM, Baron JH (1991) Simplified single sample 13Carbon urea breath test for Helicobacter 
pylori: comparison with histology, culture, and ELISA serology. Gut 32(12):1461-1464

Luchner M, Gutmann R, Bayer K, Dunkl J, Hansel A, Herbig J, Singer W, Strobl F, Winkler K, Striedner G (2012) Implementation of proton transfer reaction-mass spectrometry (PTRMS) for advanced bioprocess monitoring. Biotechnol Bioeng 109(12):3059-3069

Madden MC, Stevens T, Case M, Schmitt M, Diaz-Sanchez D, Bassett M, Montilla TS, Berntsen J, Devlin RB (2014) Diesel exhaust modulates ozone-induced lung function decrements in healthy human volunteers. Part Fibre Toxicol 11:33

Mannino DM, Ford ES, Redd SC (2003) Obstructive and restrictive lung disease and markers of inflammation: data from the third national health and nutrition examination. Am J Med 114(9):758-762

Manolis A (1983) The diagnostic potential of breath analysis. Clin Chem 29(1):5-15

Marks DM (2003) Equipment design considerations for large scale cell culture. Cytotechnology 42(1):21-33

Matz G, Lennemann F (1996) On-line monitoring of biotechnological processes by gas chromatographic-mass spectrometric analysis of fermentation suspensions. J Chromatogr A 750(1):141-149

Miekisch W, Schubert JK, Noeldge-Schomburg GF (2004) Diagnostic potential of breath analysis-focus on volatile organic compounds. Clin Chim Acta 347(1):25-39

Miekisch W, Fuchs P, Kamysek S, Neumann C, Schubert JK (2008) Assessment of propofol concentrations in human breath and blood by means of HS-SPME-GC-MS. Clin Chim Acta 395(1):32-37

Milazzo L, Piazza M, Sangaletti O, Gatti N, Cappelletti A, Adorni F, Antinori S, Galli M, Moroni M, Riva A (2005) [13C] Methionine breath test: a novel method to detect antiretroviral drugrelated mitochondrial toxicity. J Antimicrob Chemother 55(1):84-89

Miller GW, Jones DP (2014) The nature of nurture: refining the definition of the exposome. Toxicol Sci 137(1):1-2

Modak AS (2007) Stable isotope breath tests in clinical medicine: a review. J Breath Res 1(1):014003

Modak AS (2009) Single time point diagnostic breath tests: a review. J Breath Res 4(1):017002

Modak AS (2010) Breath biomarkers for personalized medicine. Personal Med 7(6):643-653

Modak AS (2013) Regulatory issues on breath tests and updates of recent advances on [13C]-breath tests. J Breath Res 7(3):037103

Moritz F, Janicka M, Zygler A, Forcisi S, Kot-Wasik A, Kot J, Gebefügi I, Namiesnik J, Schmitt-Kopplin P (2015) The compositional space of exhaled breath condensate and its link to the human breath volatilome. J Breath Res 9(2):027105

Morris JF (1976) Spirometry in the evaluation of pulmonary function. West J Med 125(2):110-118

Mutlu GM, Garey KW, Robbins RA, Danziger LH, Rubinstein I (2001) Collection and analysis of exhaled breath condensate in humans. Am J Respir Crit Care Med 164(5):731-737

Opdam FL, Modak AS, Gelderblom H, Guchelaar HJ (2015) Further characterization of a 13C-dextromethorphan breath test for CYP2D6 phenotyping in breast cancer patients on tamoxifen therapy. J Breath Res 9(2):026003

Parker GJ, Law TL, Lenoch FJ, Bolger RE (2000) Development of high throughput screening assays using fluorescence polarization: nuclear receptor-ligand-binding and kinase/phosphatase assays. J Biomol Screen 5(2):77-88

Patel CJ, Bhattacharya J, Butte AJ (2010) An environment-wide association study (EWAS) on type 2 diabetes mellitus. PLoS One 5(5): 10746

Pelclova D, Barosova H, Kukutschova J, Zdimal V, Navratil T, Fenclova Z, Vlckova S, Schwarz J, Zikova N, Kacer P, Komarc M
(2015) Raman microspectroscopy of exhaled breath condensate and urine in workers exposed to fine and nano $\mathrm{TiO}_{2}$ particles: a cross-sectional study. J Breath Res 9(3):036008

Pellizzari ED, Wallace LA, Gordon SM (1992) Elimination kinetics of volatile organics in humans using breath measurements. $\mathbf{J}$ Expo Anal Environ Epidemiol 2(3):341-356

Penttinen P, Timonen KL, Tiittanen P, Mirme A, Ruuskanen J, Pekkanen J (2001) Number concentration and size of particles in urban air: effects on spirometric lung function in adult asthmatic subjects. Environ Health Perspect 109(4):319-323

Perbellini L, Princivalle A, Cerpelloni M, Pasini F, Brugnone F (2003) Comparison of breath, blood and urine concentrations in the biomonitoring of environmental exposure to 1, 3-butadiene, 2, 5-dimethylfuran, and benzene. Int Arch Occup Environ Health 76(6):461-466

Pleil JD (2008) Role of exhaled breath biomarkers in environmental health science. J Toxicol Environ Health Part B 11(8):613-629

Pleil JD (2012) Categorizing biomarkers of the human exposome and developing metrics for assessing environmental sustainability. $\mathbf{J}$ Toxicol Environ Health Part B Crit Rev 15:264-280

Pleil JD (2016) Cellular respiration: recreating in vivo systems biology for in vitro exploration of human exposome and microbiome biomarkers. J Breath Res 10:010201

Pleil JD, Isaacs KK (2016) High-resolution mass spectrometry: basic principles for using exact mass and mass defect for discovery analysis of organic molecules in blood, breath, urine and environmental media. J Breath Res 10:012001

Pleil JD, Lindstrom AB (1997) Exhaled human breath measurement method for assessing exposure to halogenated volatile organic compounds. Clin Chem 43(5):723-730

Pleil JD, Lindstrom AB (1998) Sample timing and mathematical considerations for modeling breath elimination of volatile organic compounds. Risk Anal 18(5):585-602

Pleil JD, Stiegel MA (2013) The evolution of environmental exposure science: using breath-borne biomarkers for "discovery" of the human exposome. Feature Artic Anal Chem 85:9985-9990

Pleil JD, Kim D, Prah J, Ashley DL, Rappaport SM (2007) Exposure reconstruction for reducing uncertainty in risk assessment: example using MTBE biomarkers and a simple pharmacokinetic model. Biomarkers 12(4):331-348

Pleil JD, Hubbard HF, Sobus JR, Sawyer K, Madden MC (2008) Volatile polar metabolites in exhaled breath condensate (EBC): collection and analysis. J Breath Res 2(2):026001

Pleil JD, Stiegel MA, Sobus JR (2011) Breath biomarkers in environmental health science: exploring patterns in the human exposome. J Breath Res 5(4):046005

Pleil JD, Miekisch W, Stiegel MA, Beauchamp JD (2014a) Extending breath analysis to the cellular level: current thoughts on the human microbiome and the expression of organic compounds in the human exposome. J Breath Res 8:029001

Pleil JD, Stiegel MA, Fent KW (2014b) Exploratory breath analyses for assessing toxic dermal exposures of firefighters during suppression of structural burns. J Breath Res 8:037107

Pleil JD, Miekisch W, Beauchamp JD, Funk WE (2015) Adapting biomarker technologies to adverse outcome pathways (AOPs) research: current thoughts on using in vivo discovery for developing in vitro target methods. J Breath Res 9:039001

Polk DB, Peek RM (2010) Helicobacter pylori: gastric cancer and beyond. Nat Rev Cancer 10(6):403-414

Possemiers S, Grootaert C, Vermeiren J, Gross G, Marzorati M, Verstraete W, Van de Wiele T (2009) The intestinal environment in health and disease-recent insights on the potential of intestinal bacteria to influence human health. Pharm Des 15(18):2051-2065

Rager JE, Strynar MJ, Liang S, McMahen RL, Richard AM, Grulke CM, Wambaugh JF, Isaacs KK, Judson R, Williams AJ, Sobus 
JR (2016) Linking high resolution mass spectrometry data with exposure and toxicity forecasts to advance high-throughput environmental monitoring. Environ Int 88:269-280

Rappaport SM (2011) Implications of the exposome for exposure science. J Expo Sci Environ Epidemiol 21:5-9

Rappaport SM (2012) Biomarkers intersect with the exposome. Biomarkers 17(6):483-489

Rappaport SM, Smith MT (2010) Environment and disease risks. Science 330(6003):460-461

Rappaport SM, Barupal DK, Wishart D, Vineis P, Scalbert A (2014) The blood exposome and its role in discovering causes of disease. Environ Health Perspect 122(8):769-774

Risby TH, Pleil JD (2014) CSI: breathprint, (invited editorial). Anal Sci 14:22-23

Risby TH, Solga SF (2006) Current status of clinical breath analysis. Appl Phys B 85(2-3):421-426

Santini G, Mores N, Shohreh R, Valente S, Dabrowska M, Trové A, Zini G, Cattani P, Fuso L, Mautone A, Mondino C (2016) Exhaled and non-exhaled non-invasive markers for assessment of respiratory inflammation in patients with stable COPD and healthy smokers. J Breath Res 10(1):017102

Savides MC, Oehme FW (1983) Acetaminophen and its toxicity. J Appl Toxicol 3(2):96-111

Scannell C, Chen L, Aris RM, Tager I, Christian D, Ferrando R, Welch B, Kelly T, Balmes JR (1996) Greater ozone-induced inflammatory responses in subjects with asthma. Am J Respir Crit Care Med 154(1):24-29

Schellekens RC, Stellaard F, Woerdenbag HJ, Frijlink HW, Kosterink JG (2011) Applications of stable isotopes in clinical pharmacology. Br J Clin Pharmacol 72(6):879-897

Seemann R, Conceicao MD, Filippi A, Greenman J, Lenton P, Nachnani S, Quirynen M, Roldan S, Schulze H, Sterer N, Tangerman A, Winkel EG, Yaegaki K, Rosenberg M (2014) Halitosis management by the general dental practitioner-results of an international consensus workshop. J Breath Res 8(1):017101

Sethi S, Nanda R, Chakraborty T (2013) Clinical application of volatile organic compound analysis for detecting infectious diseases. Clin Microbiol Rev 26(3):462-475

Sexton K, Needham LL, Pirkle JL (2004) Measuring chemicals in human tissues is the "gold standard" for assessing people's exposure to pollution. Am Sci 92:38-45

Shestivska V, Dryahina K, Nunváŕ J, Sovová K, Elhottová D, Nemec A, Smith D, Španěl P (2015) Quantitative analysis of volatile metabolites released in vitro by bacteria of the genus Stenotrophomonas for identification of breath biomarkers of respiratory infection in cystic fibrosis. J Breath Res 9(2):027104

Shimada T, Yamazaki H, Mimura M, Inui Y, Guengerich FP (1994) Interindividual variations in human liver cytochrome P-450 enzymes involved in the oxidation of drugs, carcinogens and toxic chemicals: studies with liver microsomes of 30 Japanese and 30 Caucasians. J Pharmacol Exp Ther 270(1):414-423

Skogstrand K, Thorsen P, Nørgaard-Pedersen B, Schendel DE, Sørensen LC, Hougaard DM (2005) Simultaneous measurement of 25 inflammatory markers and neurotrophins in neonatal dried blood spots by immunoassay with xMAP technology. Clin Chem 51(10):1854-1866

Sleator RD (2010) The human superorganism of microbes and men. Med Hypotheses 74(2):214-215

Smith MT, Rappaport SM (2009) Building exposure biology centers to put the E into" $\mathrm{G} \times \mathrm{E}$ " interaction studies. Environ Health Perspect 117(8):A334

Smith D, Śpaněl P (2005) Selected ion flow tube mass spectrometry (SIFT-MS) for on-line trace gas analysis. Mass Spectrom Rev 24(5):661-700
Smith D, Španěl P (2011) Direct, rapid quantitative analyses of BVOCs using SIFT-MS and PTR-MS obviating sample collection. TrAC Trends Anal Chem 30(7):945-959

Smith D, Engel B, Diskin AM, Španěl P, Davies SJ (2002) Comparative measurements of total body water in healthy volunteers by online breath deuterium measurement and other near-subject methods. Am J Clin Nutr 76(6):1295-1301

Soldatow VY, LeCluyse EL, Griffith LG, Rusyn I (2013) In vitro models for liver toxicity testing. Toxicol Res 2(1):23-39

Soyer OU, Dizdar EA, Keskin O, Lilly C, Kalayci O (2006) Comparison of two methods for exhaled breath condensate collection. Allergy 61(8):1016-1018

Španěl P, Smith D (1996) Selected ion flow tube: a technique for quantitative trace gas analysis of air and breath. Med Biol Eng Comput 34(6):409-419

Spliethoff HM, Tao L, Shaver SM, Aldous KM, Pass KA, Kannan K, Eadon GA (2008) Use of newborn screening program blood spots for exposure assessment: declining levels of perfluorinated compounds in New York State infants. Environ Sci Technol 42(14):5361-5367

Spooner N, Lad R, Barfield M (2009) Dried blood spots as a sample collection technique for the determination of pharmacokinetics in clinical studies: considerations for the validation of a quantitative bioanalytical method. Anal Chem 81(4):1557-1563

Stamyr K, Mörk AK, Johanson G (2015) Physiologically based pharmacokinetic modeling of hydrogen cyanide levels in human breath. Arch Toxicol 89(8):1287-1296

Stiegel MA, Pleil JD, Sobus JR, Morgan MK, Madden MC (2015) Analysis of inflammatory cytokines in human blood, breath condensate, and urine using a multiplex immunoassay platform. Biomarkers 20(1):35-46

Stix G (2003) Breath takers. Sci Am 289(6):26-28

Sun S, Schiller JH, Gazdar AF (2007) Lung cancer in never smokers-a different disease. Nat Rev Cancer 7(10):778-790

Teeguarden JG, Tan C, Edwards S, Leonard JA, Anderson KA, Corley RA, Harding A, Kile ML, Massey Simonich S, Stone D, Waters KM (2016) Completing the link between exposure science and toxicology for improved environmental health decision making: the aggregate exposure pathway framework. Environ Sci Technol 50(9):4579-4586

Thomas DJ, Styblo M, Lin S (2001) The cellular metabolism and systemic toxicity of arsenic. Toxicol Appl Pharmacol 176(2):127-144

Tice RR, Austin CP, Kavlock RJ, Bucher JR (2013) Improving the human hazard characterization of chemicals: a Tox21 update. Environ Health Perspect 121(7):756-765

Tollefsen KE, Scholz S, Cronin MT, Edwards SW, de Knecht J, Crofton K, Garcia-Reyero N, Hartung T, Worth A, Patlewicz G (2014) Applying adverse outcome pathways (AOPs) to support integrated approaches to testing and assessment (IATA). Regul Toxicol Pharmacol 70(3):629-640

Traucher J, Hansel A, Lindinger W (1996) Analysis of compounds in human breath after ingestion of garlic using protontransfer-reaction mass spectrometry. J Agric Food Chem 44(12):3778-3782

Tu RH, Mitchell CS, Kay GG, Risby TH (2004) Human exposure to the jet fuel, JP-8. Aviat Space Environ Med 75(1):49-59

Ussher JR, Lopaschuk GD, Arduini A (2013) Gut microbiota metabolism of L-carnitine and cardiovascular risk. Atherosclerosis 231(2):456-461

Vaittinen O, Manfred Schmidt F, Metsala M, Halonen L (2013) Exhaled breath biomonitoring using laser spectroscopy. Curr Anal Chem 9(3):463-475

Vrijheid M, Robinson O, Basagaña Flores X, Bustamante Pineda M, Casas M, Estivill X, van Gent D, González Ruiz JR, Júlvez Calvo J, Kogevinas M, Sabidó E (2014) The human early-life 
exposome (HELIX): project rationale and design. Environ Health Perspect 122(6):535-544

Wallace LA, Pellizzari ED (1987) Personal air exposures and breath concentrations of benzene and other volatile hydrocarbons for smokers and nonsmokers. Toxicol Lett 35(1):113-116

Wallace L, Buckley T, Pellizzari E, Gordon S (1986) Breath measurements as volatile organic compound biomarkers. Environ Health Perspect 104(Suppl 5):861-869

Wallace L, Pellizzari E, Hartwell TD, Perritt R, Ziegenfus R (1987a) Exposures to benzene and other volatile compounds from active and passive smoking. Arch Environ Health Int J 42(5):272-2679

Wallace LA, Pellizzari ED, Hartwell TD, Sparacino C, Whitmore R, Sheldon L, Zelon H, Perritt R (1987b) The TEAM study: personal exposures to toxic substances in air, drinking water, and breath of 400 residents of New Jersey, North Carolina, and North Dakota. Environ Res 43(2):290-307

Wallace LA, Pellizzari ED, Gordon SM (1993) A linear model relating breath concentrations to environmental exposures: application to a chamber study of four volunteers exposed to volatile organic chemicals. J Expo Anal Environ Epidemiol 3(1):75-103

Walsh ME, Macleod DA (1983) Breath alcohol analysis in the accident and emergency department. Injury 15(1):62-66
Wester RC, Maibach HI, Gruenke LD, Craig JC (1986) Benzene levels in ambient air and breath of smokers and nonsmokers in urban and pristine environments. J Toxicol Environ Health Part A 18(4):567-573

Wild CP (2005) Complementing the genome with an "exposome": the outstanding challenge of environmental exposure measurement in molecular epidemiology. Cancer Epidemiol Biomark Prev 14:1847-1850

Wild CP (2012) Complementing the genome with an "exposome": the outstanding challenge of environmental exposure measurement in molecular epidemiology. Cancer Epidemiol Biomark Prev 14(8): $1847-1850$

Williams J, Pleil J (2016) Crowd-based breath analysis: assessing behavior, activity, exposures, and emotional response of people in groups. J Breath Res 10(3):032001

Williams J, Stönner C, Wicker J, Krauter N, Derstroff B, Bourtsoukidis E, Klüpfel T, Kramer (2016) Cinema audiences reproducibly vary the chemical composition of air during films, by broadcasting scene specific emissions on breath. Sci Rep 6:25464

Zhu J, Bean HD, Wargo MJ, Leclair LW, Hill JE (2013) Detecting bacterial lung infections: in vivo evaluation of in vitro volatile fingerprints. J Breath Res 7(1):016003 